\title{
What's on the menu? A review of the energy and nutritional content of US chain restaurant menus
}

\author{
Helen W Wu* and Roland Sturm \\ RAND Corporation, 1776 Main St, PO Box 2138, Santa Monica, CA 90407, USA
}

Submitted 13 September 2011: Final revision received 8 March 2012: Accepted 15 March 2012: First published online 11 May 2012

\begin{abstract}
Objective: The present study aimed to (i) describe the availability of nutrition information in major chain restaurants, (ii) document the energy and nutrient levels of menu items, (iii) evaluate relationships with restaurant characteristics, menu labelling and trans fat laws, and nutrition information accessibility, and (iv) compare energy and nutrient levels against industry-sponsored and government-issued nutrition criteria.

Design: Descriptive statistics and multivariate regression analysis of the energy, total fat, saturated fat, trans fat, sodium, carbohydrate and protein levels of 28433 regular and 1833 children's menu items.

Setting: Energy and nutrition information provided on restaurant websites or upon request, and secondary databases on restaurant characteristics.

Subjects: The top 400 US chain restaurants by sales, based on the 2009 list of the Restaurants \& Institutions magazine.

Results: Complete nutrition information was reported for 245 (61\%) restaurants. Appetizers had more energy, fat and sodium than all other item types. Children's menu specialty beverages had more fat, saturated fat and carbohydrates than comparable regular menu beverages. The majority of main entrées fell below one-third of the US Department of Agriculture's estimated daily energy needs, but as few as 3\% were also within limits for sodium, fat and saturated fat. Main entrées had significantly more energy, fat and saturated fat in family-style restaurants than in fast-food restaurants. Restaurants that made nutrition information easily accessible on websites had significantly lower energy, fat and sodium contents across menu offerings than those providing information only upon request.

Conclusions: The paper provides a comprehensive view of chain restaurant menu nutrition prior to nationwide labelling laws. It offers baseline data to evaluate how restaurants respond after laws are implemented.
\end{abstract}

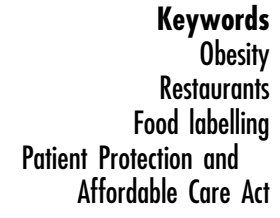

Obesity

Restaurants

Protection and Affordable Care Act
Restaurants play a major role in the American diet, with $82 \%$ of US adults eating out at least once weekly ${ }^{(1)}$. Restaurant meals have increased their contribution to total energy intake over time ${ }^{(2)}$ and increased consumption of food away from home is associated with poorer diet quality and higher intakes of energy, fat and sodium ${ }^{(3)}$.

Consumers cannot accurately estimate the nutritional content of restaurant foods and several states and municipalities, led by New York City in 2008, passed menu labelling laws ${ }^{(4)}$. These initial efforts were superseded by the Patient Protection and Affordable Care Act of 2010 (ACA), which made energy (calorie) labelling on menus a national requirement for restaurants with twenty or more outlets nationwide as of March 2010, although some provisions do not take effect until the Food and Drug Administration finalizes regulations ${ }^{(5)}$, expected in 2012.

The discussion on the effects of menu labelling has focused almost exclusively on consumer responses to a fixed menu ${ }^{(6-11)}$. Business responses are not well documented in the research, despite the fact that restaurants regularly introduce new items and occasionally reformulate existing ones. In fact, there is not even a comprehensive assessment of nutrient information across the restaurant industry, an essential requirement for future evaluations of the federal legislation. The present research fills this gap by describing how chain restaurant menu offerings shape the food environment faced by children and adults.

Two prior studies analysed the availability of nutrition information and one analysed menu nutritional content. In $2004,44 \%$ of the 300 largest US chain restaurants by sales provided nutrition information on websites or upon request $^{(12)}$. Also in 2004, among fifteen table service chain restaurants operating in Minnesota, ten provided some nutrition information but nine of these ten only provided data for items with specific health claims, such as 'heart healthy' or 'low fat ${ }^{\text {(13) }}$. It is likely that these rates changed 
substantially even before passage of the ACA, due to state and local regulations. One study considered nutritional content of restaurant menus, but it was limited to twelve fast-food restaurants ${ }^{(14)}$. Population-based dietary survey studies have analysed self-reported intake, but energy and nutrient values were estimated indirectly from databases ${ }^{(15)}$.

The present paper reports the status of data availability and nutritional content of menus in the largest US chain restaurants just prior to passage of the ACA. It analyses the availability of data, updating results from earlier studies, and provides the first study that systematically analyses nutritional content across such an extensive and diverse of set of restaurants. Research questions are:

1. What is the availability of data on standard menu offerings at major US chain restaurants?

2. What are the energy and nutrient levels of these menu offerings?

3. How do these levels relate to restaurant characteristics, existing state/local labelling laws or trans fat bans, and ease of data accessibility?

4. What proportion of items appears to meet restaurant industry-supported and government-issued nutrition criteria? 'Sodium', as used throughout the present paper, refers to table salt, which is predominantly $\mathrm{NaCl}$.

\section{Methods}

\section{Study population}

The study population was identified by the 2009 Restaurants E Institutions magazine's list of the top 400 US chain restaurants based on 2008 sales $^{(16)}$. These restaurants combined had 206750 US outlets, representing approximately one-third of all US restaurant outlets in 2010 based on analysis from the InfoUSA database ${ }^{(17)}$.

\section{Data collection}

Data were collected from February to May 2010 by reviewing restaurant websites for nutrition information. The data collection time frame overlaps with when the menu labelling provision of the ACA was passed (March 2010), but federal implementation rules were still pending in early 2012. When the website did not provide this information, an email request was sent to request it. Restaurants were counted as having complete nutrition information available if energy was listed for the majority of standard menu items. Information for selected nutrients and sodium was also collected when available: total fat, saturated fat, trans fat, total carbohydrates, sodium and protein. Data that were inconsistently reported (e.g. serving size, sugar, fibre and vitamins) were excluded. Restaurants classified as not having complete information: (i) did not offer a standard preparation for at least $50 \%$ of menu items (e.g. menu based fully on 'build-your-own' customizations; $n 5$ ); (ii) only provided information for a minority of the menu (e.g. 'healthy choices' only; $n$ 20); (iii) did not provide information on the website nor provide contact information to request it $(n 4)$; or (iv) did not provide information on a website nor respond to an email request for it ( $n$ 126). Complete nutrition information was available for 245 (61\%) restaurants, representing 176711 (85\%) outlets in the initial study population. Characteristics of the 155 (39\%) restaurants (representing 30039 (15\%) outlets) not providing complete nutrition information are described in the Results section.

Nutrition information was entered following implementation guidelines for California's menu labelling law ${ }^{(18)}$ where possible (as proposed federal guidelines were not published at the time of data entry). A key feature was that values represent the restaurant-defined single serving size for an item's standard preparation. The entire item was entered as a single serving if not specified otherwise. Add-ons/toppings and condiments were excluded unless served as part of the item's standard preparation, and alcoholic beverages were excluded. Every individual unique item and size on the standard and children's menu for selected item types (main entrée; appetizer; side; salad; salad dressing; soup; dessert/baked good specialty non-alcoholic beverage) was coded. If items had customization options, the high and low energy values were entered as separate menu items. Catering platters and family size items were excluded unless individual serving portions were noted. Items not designed for individual in-restaurant consumption were excluded (e.g. whole pies).

Indicator variables were created to compare distinct nutrition criteria (Table 1): the National Restaurant Association-supported Healthy Dining and Kids LiveWell criteria for energy, fat, saturated fat and sodium ${ }^{(19)}$, and one-third of the US Department of Agriculture (USDA) 2010 Dietary Guidelines ${ }^{(20)}$. For USDA estimated energy needs, a daily threshold of $8368 \mathrm{~kJ} / 2000 \mathrm{kcal}$ was used as the basis for adults; for children aged 4-8 and 9-13 years, the mid-range average for moderately active females and males for each respective age group was used $(6694 \mathrm{~kJ} / 1600 \mathrm{kcal}$ and $7950 \mathrm{~kJ} /$ $1900 \mathrm{kcal})^{(21)}$. Taking one-third of the USDA RDA is a conservative benchmark for a single meal, as Americans report about five eating occasions per day, typically three main meals and two snacks ${ }^{(22)}$, and fast-food restaurant visitors order an average of $2 \cdot 4$ menu items ${ }^{(23)}$. It closely follows the $32 \%$ USDA benchmark for children's dietary intake used in the Yale-Rudd Center Fast Food FACTS report ${ }^{(14)}$ and the Institute of Medicine Committee on School Meals National School Lunch Program recommendations ${ }^{(24)}$, although school lunch recommendations use different age groups and higher energy and nutrient levels in order to ensure adequate intake. Unlike school lunches which are complete meals, the present study calculated per single serving size for a main entrée, rather than for a typical meal ordered (such information is not available from the data).

Data on restaurant characteristics come from two secondary sources: (i) the Research Report for Foodservice 
Table 1 Comparison of Healthy Dining, Kids LiveWell and US Department of Agriculture (USDA) nutrition standards

\begin{tabular}{|c|c|c|c|c|c|c|c|}
\hline \multirow[b]{2}{*}{ Standard } & \multicolumn{7}{|c|}{ Maximum values } \\
\hline & $\begin{array}{l}\text { Energy } \\
\text { (kJ/kcal) }\end{array}$ & Fat $(\mathrm{g})$ & $\begin{array}{l}\% \text { of energy } \\
\text { from fat }\end{array}$ & $\begin{array}{l}\text { Saturated } \\
\text { fat }(g)\end{array}$ & $\begin{array}{l}\% \text { of energy from } \\
\text { saturated fat }\end{array}$ & $\begin{array}{l}\text { Trans } \\
\text { fat }(\mathrm{g})\end{array}$ & $\begin{array}{l}\text { Sodium } \\
\text { (mg) }\end{array}$ \\
\hline \multicolumn{8}{|l|}{ Healthy Diningt } \\
\hline Main entrée & $3138 / 750$ & 25 & $\mathrm{n} / \mathrm{a}$ & 8 & $\mathrm{n} / \mathrm{a}$ & $\mathrm{n} / \mathrm{a}$ & 2000 \\
\hline Appetizer, side or dessert & $1046 / 250$ & 8 & $\mathrm{n} / \mathrm{a}$ & 3 & $\mathrm{n} / \mathrm{a}$ & $\mathrm{n} / \mathrm{a}$ & 750 \\
\hline USDA, adults $\ddagger$ & $2791 / 667$ & $\mathrm{n} / \mathrm{a}$ & 35 & $\mathrm{n} / \mathrm{a}$ & 10 & $1 \|$ & 767 \\
\hline USDA, adults with low sodium needs $\ddagger$ & $2791 / 667$ & $\mathrm{n} / \mathrm{a}$ & 35 & $\mathrm{n} / \mathrm{a}$ & 10 & $1 \|$ & 500 \\
\hline \multicolumn{8}{|l|}{ Kids LiveWellt§ } \\
\hline Children's meal & $2510 / 600$ & $\mathrm{n} / \mathrm{a}$ & 35 & $\mathrm{n} / \mathrm{a}$ & 10 & 0.5 & 770 \\
\hline Side & $837 / 200$ & $\mathrm{n} / \mathrm{a}$ & 35 & $\mathrm{n} / \mathrm{a}$ & 10 & 0.5 & 250 \\
\hline USDA, children aged 4-8 yearstł & $2230 / 533$ & $\mathrm{n} / \mathrm{a}$ & 35 & $\mathrm{n} / \mathrm{a}$ & 10 & $1 \|$ & 633 \\
\hline USDA, children aged $9-13$ yearsł & $2649 / 633$ & $\mathrm{n} / \mathrm{a}$ & 35 & $\mathrm{n} / \mathrm{a}$ & 10 & $1 \|$ & 733 \\
\hline
\end{tabular}

n/a, not applicable.

tExcludes specific ingredient criteria (e.g. inclusion of whole grains, lean meats), for which data were not collected.

‡Represents one-third of estimated daily energy needs and recommended daily intake (RDA) limits for each group. USDA criteria were applied to main entrées only, which were recorded as à la carte items whenever possible.

§Excludes criterion for percentage of energy from total sugars, for which data were not collected.

॥No specific limit recommended other than 'as little as possible'. The analysis used $<1 \mathrm{~g}$ as a benchmark.

(based on the Restaurantchains.net database), a tri-annual telephone survey of restaurant executives, provided data on restaurant operating characteristics ${ }^{(25)}$; and (ii) the InfoUSA 2010 business database provided outlets by location $^{(17)}$. Finally, a literature review was conducted to identify menu labelling laws and trans fat bans at the city, county and state levels that were effective prior to data collection and might influence the formulation of restaurant menu offerings ${ }^{(26-29)}$. The analytic variable is the percentage of a restaurant's outlets subject to such laws.

\section{Statistical analysis}

Analysis was done using the Stata/IC statistical software package version $10 \cdot 1$ (StataCorp LP, College Station, TX, USA). In addition to descriptive statistics, a logistic regression model analysed whether or not a restaurant provided complete energy information (as the dependent variable) as a function of restaurant characteristics. For restaurants with complete nutrition information, energy and nutrient values of main entrées were analysed using ordinary least-squares multivariate regression with robust standard errors and clustered residuals by restaurant, with no weighting by number of outlets. Main entrées with energy content less than $418 \mathrm{~kJ} / 100 \mathrm{kcal}$ or greater than $20921 \mathrm{~kJ} / 5000 \mathrm{kcal}$ were excluded; despite being listed as main entrées, those items typically represented substantially less/more than a full meal for one individual (e.g. one chicken wing or fifty chicken wings).

Independent variables were restaurant characteristics (meal periods offered; service model; cuisine type; national outlet count), degree of web-based information accessibility (readily accessible in one page/file; requiring multiple clicks to view information per item; requiring an email request for information) and percentage of the restaurant's outlets subject to an existing menu labelling or trans fat policy. Outlet count was analysed as a decile-level variable, probably a more robust data specification than outlet counts, which had a highly skewed distribution owing to a few restaurants with a very large number of outlets.

\section{Results}

\section{Restaurant characteristics}

Characteristics for the initial study population are shown in Table 2. By service type, family style accounted for the most brands, but fast food accounted for the most outlets. By cuisine, the largest number of brands served American cuisine, but the largest number of outlets served snacks, burgers or sandwiches (although American cuisine was fourth). The reason is that the number of outlets varies by service type and cuisine.

\section{Predictors of information accessibility}

Logistic regression analyses were used to estimate the odds ratio of reporting nutrition information at the $P<0.05$ significance level, using the initial study population of 400 restaurants to compare those that did not report complete information with those that did. By service type, fast casual restaurants had significantly higher odds $(\mathrm{OR}=3 \cdot 06$, $95 \%$ CI $1.08,8 \cdot 65)$ of providing nutrition information than fast-food restaurants and upscale restaurants were significantly less likely to do so $(\mathrm{OR}=0 \cdot 21,95 \%$ CI $0 \cdot 05$, 0.92), with no significant differences by other service types. By cuisine, burger and sandwich restaurants had significantly higher odds $(\mathrm{OR}=7 \cdot 16,95 \% \mathrm{CI} 1 \cdot 47,34 \cdot 84$ and $\mathrm{OR}=7 \cdot 61,95 \%$ CI $1 \cdot 44,40 \cdot 19$, respectively) of reporting information compared with American restaurants, with no significant differences by other cuisine types. Decile of outlet count was significant at $P<0 \cdot 001(\mathrm{OR}=1 \cdot 30,95 \%$ CI $1 \cdot 17,1 \cdot 45)$; larger chains were more likely to provide information. Surprisingly, existing state/local menu labelling laws had no independent effect. Having more outlets subject to trans fat bans had a significantly higher 
Table 2 Initial study population composition by brand, outlet count and subgroup-specific non-reporting rate

\begin{tabular}{|c|c|c|c|c|}
\hline Characteristic & $\begin{array}{l}\text { No. of } \\
\text { brands }\end{array}$ & $\begin{array}{l}\text { No. of } \\
\text { outlets }\end{array}$ & $\begin{array}{l}\text { Average no. of } \\
\text { outlets per brand }\end{array}$ & $\begin{array}{l}\% \text { of brands not reporting, } \\
\text { by row subgroup }\end{array}$ \\
\hline \multicolumn{5}{|l|}{ Servicet } \\
\hline Take-out/delivery & 39 & 37356 & 958 & 23 \\
\hline Fast food & 90 & 119449 & 1327 & 21 \\
\hline Fast casual & 53 & 11842 & 223 & 17 \\
\hline Buffet & 12 & 2333 & 194 & 17 \\
\hline Family style & 172 & 34530 & 201 & 50 \\
\hline Upscale & 34 & 1240 & 36 & 88 \\
\hline Total & 400 & 206750 & & \\
\hline \multicolumn{5}{|l|}{ Cuisinet } \\
\hline American & 136 & 26162 & 192 & 46 \\
\hline Asian & 15 & 2131 & 142 & 60 \\
\hline Burger & 25 & 38330 & 1533 & 08 \\
\hline Chicken & 13 & 13618 & 1048 & 15 \\
\hline Italian & 33 & 4780 & 145 & 45 \\
\hline Mexican & 31 & 10846 & 350 & 32 \\
\hline Pizza & 30 & 24028 & 801 & 23 \\
\hline Sandwich & 21 & 33206 & 1581 & 10 \\
\hline Snack‡ & 47 & 47057 & 1001 & 23 \\
\hline Steak/seafood & 49 & 6592 & 135 & 69 \\
\hline Total & 400 & 206750 & & \\
\hline
\end{tabular}

†Service types and cuisines as reported by Restaurantchains.net database. Service type examples: take-out/delivery (Auntie Anne's, Ben and Jerry's), fast food (KFC, Burger King, McDonald's), fast casual (Au Bon Pain, Panera Bread), buffet (Golden Corral, Sizzler), family style (Denny's, Marie Callender's, Red Lobster), upscale (Capital Grill, Morton's).

‡For example, bakery, café, coffee, ice cream, frozen yoghurt, smoothie restaurants.

odds (OR $=1 \cdot 03,95 \%$ CI $1 \cdot 02,1 \cdot 04)$, but the magnitude was negligible (data not shown).

\section{Energy and nutritional content of menu offerings}

Descriptive statistics for the energy and nutrient levels of menu items, by type, are shown in Table 3. The data included 30923 unique menu items (29531 regular and 1392 children's menu items) from the 245 restaurants that provided information. All items required energy values to be included, but nutrient values were reported less consistently (trans fat in particular).

For regular menu items, appetizers stand out as having the highest values of energy, fat, saturated fat and sodium compared with all other menu item types, even main entrées. Salads combined with dressing values had nutrient values approaching those of main entrées. Quartiles are also shown. The 75th percentile, for example, means that one in four appetizers exceeds $4795 \mathrm{~kJ} / 1146 \mathrm{kcal}$ and $2660 \mathrm{mg}$ sodium, and that one in four main entrées exceeds $3724 \mathrm{~kJ} /$ $890 \mathrm{kcal}$ and $2000 \mathrm{mg}$ sodium.

Children's menu items are expected to have smaller portions, and thus be lower in nutritional content than the corresponding regular menu item type. For the most part this was true, the glaring exception being beverages. Children's menu specialty beverages had more energy, fat, saturated fat and carbohydrates at most percentiles than specialty, non-alcoholic regular menu beverages.

Figure 1 illustrates how selected item types might fare against the restaurant industry-supported Healthy Dining and Kids LiveWell nutrition criteria, for regular and children's menu items, respectively. This analysis estimates maximum percentages of items that would pass, as it did not include ingredient criteria, for which data were not available. For regular menu items, up to $42 \%$ of main entrées, $39 \%$ of sides, $16 \%$ of desserts and $6 \%$ of appetizers might pass the Healthy Dining standards. Children's menu items did not fare as well with Kids LiveWell standards, with a maximum of $11 \%$ of main entrées and $33 \%$ of sides passing, not taking into account ingredient criteria.

Figure 2 compares main entrées against the conservative benchmark of one-third of the USDA guidelines. Children's menu main entrées are compared with one-third of the USDA estimated energy intake and RDA values for two age groups defined in the USDA dietary guidelines; adolescents' needs are similar to adults' needs. The majority of main entrées fell within estimated energy needs for adults (57\%) and children (67-80\%), but fewer fell within RDA limits for fat and sodium. When main entrées were assessed to see if they fell within estimated energy needs and RDA for fat, saturated fat and sodium simultaneously, a much smaller proportion fell within these limits (between 3 and $4 \%$ for adults and 8 and $11 \%$ for children), compared with Healthy Dining and Kids LiveWell criteria. The finding suggests that the actual percentage of complete meals that meet nutritional criteria as well as energy needs, as typically consumed, is likely to be very small.

\section{Predictors of energy/nutritional content for main entrées}

Table 4 shows the results of the regression of item-level energy and nutrient variables $v$. restaurant-level variables for main entrées. Depending on the outcome measure, the model's $R^{2}$ explained between $12 \cdot 9 \%$ and $21.5 \%$ of the total variation. 
Table 3 Energy and nutritional content of chain restaurant menu offerings

\begin{tabular}{|c|c|c|c|c|c|c|c|c|c|c|c|c|c|c|}
\hline \multirow[b]{2}{*}{ Statistic } & \multicolumn{7}{|c|}{ Regular menu } & \multicolumn{7}{|c|}{ Children's menu } \\
\hline & $\begin{array}{l}\text { Energy } \\
(\mathrm{kJ} / \mathrm{kcal})\end{array}$ & $\begin{array}{l}\text { Fat } \\
(\mathrm{g})\end{array}$ & $\begin{array}{l}\text { Saturated } \\
\text { fat }(\mathrm{g})\end{array}$ & $\begin{array}{r}\text { Trans } \\
\text { fat }(\mathrm{g})\end{array}$ & $\begin{array}{l}\text { Sodium } \\
(\mathrm{mg})\end{array}$ & $\begin{array}{l}\text { Total } \\
\mathrm{CHO}(\mathrm{g})\end{array}$ & $\begin{array}{l}\text { Protein } \\
(\mathrm{g})\end{array}$ & $\begin{array}{l}\text { Energy } \\
(\mathrm{kJ} / \mathrm{kcal})\end{array}$ & $\begin{array}{l}\text { Fat } \\
(\mathrm{g})\end{array}$ & $\begin{array}{l}\text { Saturated } \\
\text { fat }(\mathrm{g})\end{array}$ & $\begin{array}{r}\text { Trans } \\
\text { fat }(\mathrm{g})\end{array}$ & $\begin{array}{c}\text { Sodium } \\
(\mathrm{mg})\end{array}$ & $\begin{array}{l}\text { Total } \\
\text { CHO }(g)\end{array}$ & $\begin{array}{l}\text { Protein } \\
(\mathrm{g})\end{array}$ \\
\hline & \multicolumn{7}{|c|}{ Main entréet } & \multicolumn{7}{|c|}{ Main entréet } \\
\hline Mean & $2820 / 674$ & 32 & 12 & 0 & 1512 & 57 & 34 & $1950 / 466$ & 21 & 8 & 0 & 956 & 47 & 19 \\
\hline P25 & $1515 / 362$ & 14 & 4 & 0 & 745 & 28 & 17 & $1276 / 305$ & 10 & 3 & 0 & 610 & 27 & 12 \\
\hline P50 & $2469 / 590$ & 25 & 9 & 0 & 1291 & 49 & 30 & $1757 / 420$ & 18 & 7 & 0 & 875 & 42 & 18 \\
\hline P75 & $3724 / 890$ & 43 & 16 & 1 & 2000 & 77 & 45 & $2506 / 599$ & 30 & 11 & 0 & 1190 & 63 & 24 \\
\hline \multirow[t]{2}{*}{$n$} & 13334 & 11204 & 12118 & 6097 & 12943 & 13058 & 10467 & 927 & 750 & 822 & 346 & 915 & 913 & 686 \\
\hline & \multicolumn{7}{|c|}{ Appetizer } & \multirow{2}{*}{\multicolumn{7}{|c|}{$\begin{array}{c}\text { Appetizer } \\
\text { No children's menu items were reported as appetizers; see sides }\end{array}$}} \\
\hline Mean & $3502 / 813$ & 48 & 16 & 1 & 2023 & 60 & 35 & & & & & & & \\
\hline P25 & $1506 / 360$ & 19 & 5 & 0 & 880 & 25 & 13 & - & - & - & - & - & - & - \\
\hline P50 & 2929/700 & 40 & 12 & 0 & 1675 & 48 & 28 & - & - & - & - & - & - & - \\
\hline P75 & $4795 / 1146$ & 68 & 22 & 0 & 2660 & 87 & 51 & - & - & - & - & - & - & - \\
\hline \multirow[t]{2}{*}{$n$} & 1191 & 925 & 1018 & 334 & 1119 & 1126 & 805 & - & - & - & - & - & - & - \\
\hline & \multicolumn{7}{|c|}{ Side } & \multicolumn{7}{|c|}{ Side } \\
\hline Mean & $1088 / 260$ & 13 & 4 & 0 & 541 & 29 & 8 & $720 / 172$ & 8 & 2 & 0 & 304 & 22 & 3 \\
\hline P25 & $473 / 113$ & 3 & 1 & 0 & 170 & 9 & 3 & $377 / 90$ & 0 & 0 & 0 & 24 & $11 \%$ & 1 \\
\hline P50 & $877 / 210$ & 9 & 2 & 0 & 410 & 23 & 5 & $665 / 159$ & 6 & 2 & 0 & 210 & 20 & 3 \\
\hline P75 & $1423 / 340$ & 17 & 5 & 0 & 730 & 41 & 10 & $1004 / 240$ & 13 & 3 & 0 & 477 & 29 & 4 \\
\hline \multirow[t]{2}{*}{$n$} & 3059 & 2685 & 2803 & 1707 & 2979 & 3000 & 2567 & 213 & 181 & 197 & 76 & 213 & 213 & 161 \\
\hline & \multicolumn{7}{|c|}{ Salad $\neq$} & \multicolumn{7}{|c|}{ Salad $\ddagger$} \\
\hline Mean & $2075 / 496$ & 28 & 8 & 0 & 1066 & 30 & 24 & $577 / 138$ & 7 & 2 & 0 & 246 & 10 & 3 \\
\hline P25 & $837 / 200$ & 9 & 3 & 0 & 400 & 12 & 6 & $251 / 60$ & 1 & 0 & 0 & 80 & 5 & 3 \\
\hline P50 & $1715 / 410$ & 21 & 6 & 0 & 897 & 20 & 21 & $473 / 113$ & 4 & 1 & 0 & 190 & 10 & 3 \\
\hline P75 & $2971 / 710$ & 40 & 12 & 0 & 1537 & 40 & 36 & $1079 / 258$ & 10 & 3 & 19 & 349 & 13 & 5 \\
\hline \multirow[t]{2}{*}{$n$} & 1815 & 1518 & 1637 & 842 & 1756 & 1777 & 1498 & 15 & 13 & 11 & 3 & 15 & 15 & 12 \\
\hline & \multicolumn{7}{|c|}{ Salad dressing } & \multicolumn{7}{|c|}{ Salad dressing } \\
\hline Mean & $720 / 172$ & 15 & 2 & 0 & 394 & 7 & 1 & $745 / 178$ & $17 \sigma^{\circ}$ & - & - & 344 & $7 \%$ & 1 \\
\hline P25 & $377 / 90$ & 6 & 1 & 0 & 220 & 2 & 0 & $416 / 100$ & 10 & - & - & 230 ฯ & 4 & 0 \\
\hline P50 & $628 / 150$ & 14 & 2 & 0 & 330 & 4 & 0 & $795 / 190$ & $20^{\circ}$ & - & - & 285 & $7 \%$ & 0 \\
\hline P75 & $983 / 235$ & 22 & 4 & 0 & 500 & 9 & 1 & $1046 / 250$ ฯ & 234 & - & - & 540 & 9 & 1 \\
\hline \multirow[t]{2}{*}{$n$} & 916 & 800 & 813 & 454 & 894 & 903 & 736 & 10 & 10 & 0 & 0 & 10 & 10 & 10 \\
\hline & \multicolumn{7}{|c|}{ Soup } & \multicolumn{7}{|c|}{ Soup } \\
\hline Mean & $941 / 225$ & 11 & 5 & 0 & 1055 & 22 & 9 & $695 / 166$ & 6 & 4 & - & 926 & 17 & 10 \\
\hline P25 & $502 / 120$ & 3 & 1 & 0 & 722 & 14 & 5 & $711 / 170^{-}$ & 1 & 3 & - & 826 & 14 & 2 \\
\hline P50 & $837 / 200$ & 8 & 3 & 0 & 990 & 20 & 8 & $753 / 180$ & 6 & 4 & - & 920 & 19 & 10 \\
\hline P75 & $1172 / 280$ & 16 & 7 & 0 & 1312 & 27 & 11 & $795 / 190$ & 10 & 5 & - & 1050 & 19 & $17 \%$ \\
\hline$n$ & 1418 & 1270 & 1291 & 929 & 1399 & 1410 & 1256 & 9 & 2 & 9 & 0 & 9 & 9 & 2 \\
\hline & & & Specialty nor & alcoholic & everage§ & & & & & Specialty & -alcoholi & everage & & \\
\hline Mean & $1749 / 418$ & 13 & 8 & 0 & 209 & 69 & 8 & $1699 / 406$ & $15^{\circ}$ & 119 & 0 & 179 & 63 & 7 \\
\hline P25 & $920 / 220$ & 1 & 0 & 0 & 85 & 39 & 3 & 1699/279 & 39 & $6 \pi$ & 0 & 59 & 52 ฯ & 2 \\
\hline P50 & $1506 / 360$ & 8 & 5 & 0 & 170 & 63 & 7 & $1799 / 430$ & 15 & 139 & 0 & 172 ब & $65^{\circ}$ & 10 \\
\hline P75 & 2343560 & 18 & 12 & 0 & 290 & 93 & 11 & $2176 / 520$ & $20^{\circ}$ & $14^{\circ}$ & 0 & 280 & 73 & 11 \\
\hline$n$ & 3286 & 2936 & 3017 & 2208 & 3149 & 3267 & 2907 & 84 & 78 & 64 & 13 & 84 & 84 & 70 \\
\hline
\end{tabular}




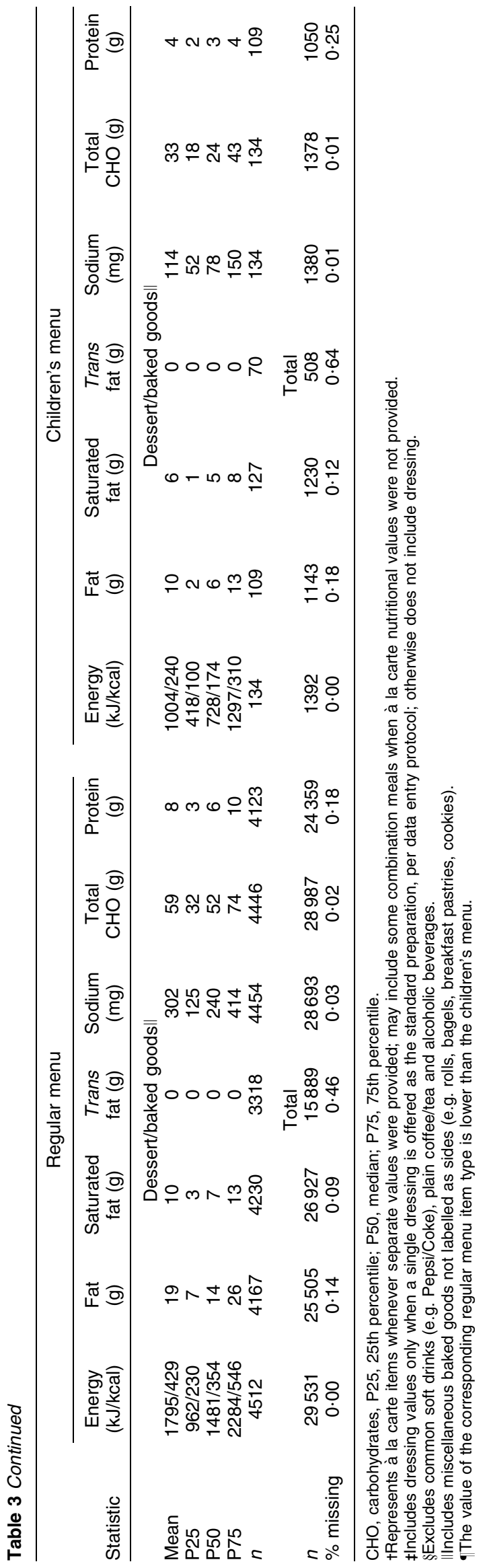

Across all outcome measures, family-style restaurant menu items consistently had significantly higher levels of energy, fat and sodium compared with fast-food restaurants, and coefficients were large. Fast casual restaurant menu items also had significantly higher energy levels on average, but not significantly higher levels of fat or sodium. The menus for restaurants serving breakfast had lower energy, sodium and protein levels, on average. Pizza and chicken restaurant menu items had significantly lower levels of most nutrients compared with American restaurant menu items. Most cuisines had significantly lower levels of sodium than American, with some large effect sizes.

While the regression analysis is limited to restaurants providing nutrition information, there were differences in how easily information could be accessed online. Restaurants that only provided information upon email request had significantly higher energy and nutrient values than those that provided the information on their website in a readily accessible single file or page. There was no significant effect for the proportion of outlets subject to a state/local labelling policy, and while coefficients for the proportion of outlets subject to a trans fat ban were significant, their magnitude was essentially zero.

\section{Discussion}

The present paper provides a snapshot of the availability of nutrition information and nutritional content of menu offerings among the largest US restaurant chains just before the ACA mandate that required nationwide menu labelling of energy (calories). Prior research has documented the impact of restaurant dining on overall diet quality ${ }^{(3,30)}$ and nutritional content in selected fast-food restaurants ${ }^{(14)}$, but none has systematically sampled this many restaurants across such diverse service types and cuisines.

One reason for the absence of prior studies was the lack of nutrition information in the past. Harnack found that only three of fifteen table service restaurants provided complete nutrition information on their websites in 2004-2005 and no restaurant without website information provided it upon email request ${ }^{(13)}$. Wootan and Osbourn found that $44 \%$ of US chains in the Restaurant \& Institutions magazine list reported complete nutrition information on websites in $2004^{(12)}$, compared with the present study's $61 \%$ in 2010 . The increase may stem from enhanced website content, consumer demand for information and state/ local laws requiring nutrition information. The present study updates and expands on prior research by reporting on how nutrition information accessibility varies by cuisine and service type, finding evidence that restaurants making information less readily accessible also have menus that are higher in energy, fat and sodium.

Although the present study provides a more extensive measure of nutritional content in the largest US chain restaurants than previously available, there are multiple 
(a)

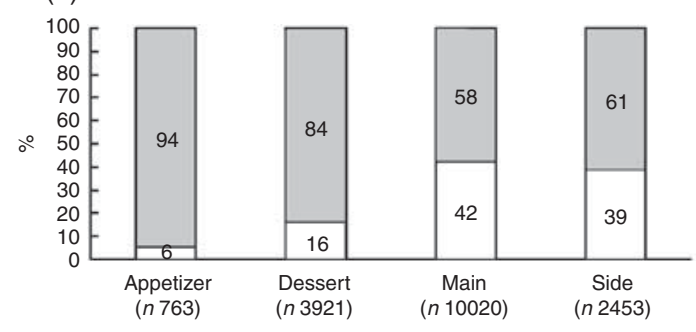

(b)

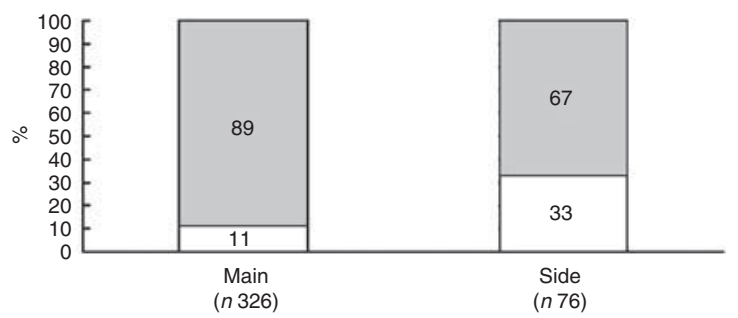

Fig. 1 Menu items meeting $(\square)$ or not meeting ( $\square$ ) nutrition criteria by item type: (a) Healthy Dining criteria, regular menus; (b) Kids LiveWell criteria†, children's menus. †Sample size is reduced as analysis includes only menu items with data reported for all nutrition criteria. Data were not available on percentage of energy from sugar (for Kids LiveWell standards) or ingredients (e.g. item includes whole grains, fruits and vegetables, for both standards), so the percentage of items approved estimates maximum possible values
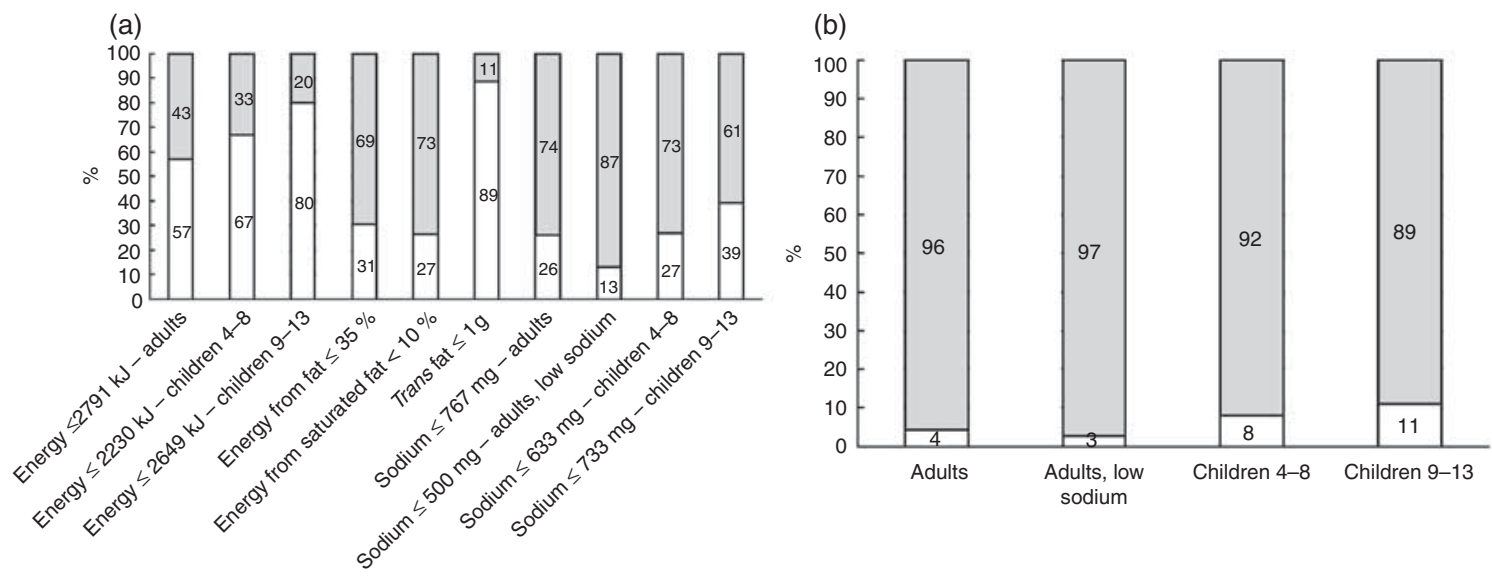

Fig. 2 Main entrées meeting ( $\square$, within recommended limit) or not meeting ( $\square$, above recommended limit) subgroup-specific values of one-third of the US Department of Agriculture (USDA) estimated daily energy needs and RDA: (a) individual nutritional values $† \S ;$ (b) across multiple USDA guidelines (energy, sodium and percentage of energy from fat/saturated fat§). $\dagger 2791 \mathrm{~kJ}=667 \mathrm{kcal} ; 2230 \mathrm{~kJ}=533 \mathrm{kcal} ; 2649 \mathrm{~kJ}=633 \mathrm{kcal}$. $\ddagger U S D A$ recommendation for trans fat is 'as little as possible'; $\leq 1 \mathrm{~g}$ was used as a benchmark. §Values for children were assessed against children's menu main entrées

limitations. Because data were intentionally collected prior to complete ACA implementation, the self-reported and usually web-based nutrition information was not subject to standardized format requirements and is likely to have variable accuracy. The restaurants studied capture a large share of the market, but large chains are obviously not representative of the universe of all restaurants. One market research group estimated that $37 \%$ of restaurant brands are independents, not chains or non-commercial operations $^{(31)}$. Individual restaurants and small chains may offer food with systematically different nutritional content, but they are not subject to menu labelling laws. We cannot comment on nutritional content for restaurants that did not make information available. Even among the largest US restaurants, those with fewer outlets and those considered 'upscale' (e.g. Legal Sea Foods, Ruth's Chris Steak House) are less likely to report data. Upscale restaurant websites often noted that accurate nutritional analysis was not possible, due to customizations and less strictly standardized food preparation methods. Results for upscale restaurants and trans fat levels should be viewed with caution, due to high non-reporting rates and thus probable reporting bias. Finally, comparison with Healthy Dining and Kids LiveWell standards was based on available data, which notably did not include sugar or ingredients additional criteria needed to determine whether items fully met those standards. The proportion of menu items characterized as meeting those standards is therefore higher than it would be if full data were available.

The present study describes energy and nutrient levels of menu offerings in order to provide a baseline set of values on the critical supply-side issue about what restaurants offer, but it is not a study of how menu offerings affect demand, choice or dietary quality. It did not evaluate the influence of price, marketing or bundling/combination meal strategies, which are known to be highly influential ${ }^{(32,33)}$, or ordering/intake patterns ${ }^{(34)}$. The present study analysed items without weighting either by sales or outlets, although restaurants with more outlets will have a bigger impact on the American diet.

Main entrées appear surprisingly low in energy when viewed à la carte and on a per-serving basis, but nevertheless have high levels of sodium or saturated fat. This may be an artifice of restaurant-determined single serving 
Table 4 Linear regression: energy and nutrition

\begin{tabular}{|c|c|c|c|c|c|c|c|c|c|c|c|c|}
\hline \multirow[b]{3}{*}{ Independent variable } & \multicolumn{12}{|c|}{ Dependent variable } \\
\hline & \multicolumn{2}{|c|}{ Energy (kJ/kcal) } & \multicolumn{2}{|c|}{ Total fat $(\mathrm{g})$} & \multicolumn{2}{|c|}{ Saturated fat $(\mathrm{g})$} & \multicolumn{2}{|c|}{ Sodium (mg) } & \multicolumn{2}{|c|}{ Carbohydrates (g) } & \multicolumn{2}{|c|}{ Protein $(\mathrm{g})$} \\
\hline & Coefficient & $P$ & Coefficient & $P$ & Coefficient & $P$ & Coefficient & $P$ & Coefficient & $P$ & Coefficient & $P$ \\
\hline \multicolumn{13}{|l|}{ Restaurant characteristics } \\
\hline Serves breakfast & $-475 \cdot 3 /-113 \cdot 6$ & $0.007^{*}$ & $-5 \cdot 2$ & 0.051 & $-1 \cdot 3$ & 0.236 & $-374 \cdot 8$ & $0.000^{\star}$ & $-5 \cdot 7$ & $0 \cdot 153$ & $-9 \cdot 8$ & $0.000^{*}$ \\
\hline Serves lunch & $-192 \cdot 9 /-46 \cdot 1$ & 0.698 & $10 \cdot 8$ & $0 \cdot 545$ & $-0 \cdot 2$ & 0.965 & $-176 \cdot 2$ & 0.629 & $-4 \cdot 5$ & 0.665 & 3.9 & 0.576 \\
\hline Serves dinner & $-282 \cdot 4 /-67 \cdot 5$ & 0.229 & -0.6 & $0 \cdot 826$ & $-2 \cdot 7$ & 0.259 & $66 \cdot 6$ & $0 \cdot 782$ & $-15 \cdot 7$ & $0 \cdot 167$ & $3 \cdot 3$ & 0.672 \\
\hline \multicolumn{13}{|l|}{ Service (ref.: fast food) } \\
\hline Take-out/delivery & $296 \cdot 2 / 70 \cdot 8$ & 0.057 & $5 \cdot 1$ & $0 \cdot 026^{*}$ & $2 \cdot 0$ & $0.022^{*}$ & $260 \cdot 4$ & $0 \cdot 046^{\star}$ & $2 \cdot 7$ & $0 \cdot 650$ & $4 \cdot 5$ & $0 \cdot 155$ \\
\hline Fast casual & $449 \cdot 4 / 107 \cdot 4$ & $0.033^{*}$ & 3.5 & $0 \cdot 238$ & $0 \cdot 8$ & $0 \cdot 407$ & $131 \cdot 7$ & 0.299 & $13 \cdot 8$ & $0.010^{\star}$ & $8 \cdot 0$ & $0.016^{\star}$ \\
\hline Buffet & $-514 \cdot 2 /-122 \cdot 9$ & 0.099 & $-5 \cdot 0$ & $0 \cdot 200$ & $-1 \cdot 9$ & $0 \cdot 172$ & $-273 \cdot 2$ & $0 \cdot 212$ & $-14 \cdot 3$ & 0.099 & $-5 \cdot 7$ & $0 \cdot 175$ \\
\hline Family style & $1132 \cdot 2 / 270 \cdot 6$ & $0 \cdot 000^{*}$ & $16 \cdot 3$ & $0.000^{*}$ & $5 \cdot 4$ & $0.000^{*}$ & $434 \cdot 5$ & $0.000^{*}$ & $18 \cdot 5$ & $0.000^{*}$ & $13 \cdot 5$ & $0.000^{*}$ \\
\hline Upscale & $-554 \cdot 0 /-132 \cdot 4$ & 0.503 & -0.6 & 0.974 & $-2 \cdot 1$ & 0.696 & $-847 \cdot 3$ & 0.090 & $-24 \cdot 9$ & $0 \cdot 141$ & $10 \cdot 4$ & $0 \cdot 214$ \\
\hline \multicolumn{13}{|l|}{ Outlet count } \\
\hline Decile of outlet count & $-2 \cdot 9 /-0 \cdot 7$ & 0.917 & $0 \cdot 1$ & $0 \cdot 820$ & $0 \cdot 0$ & $0 \cdot 830$ & $18 \cdot 8$ & $0 \cdot 262$ & $0 \cdot 3$ & 0.679 & $-0 \cdot 3$ & 0.370 \\
\hline \multicolumn{13}{|l|}{ Cuisine (ref.: American) } \\
\hline Asian & $-907 \cdot 5 /-216 \cdot 9$ & 0.069 & $-19 \cdot 4$ & $0.004^{*}$ & $-7 \cdot 1$ & $0.005^{\star}$ & $-446 \cdot 2$ & $0.021^{\star}$ & $2 \cdot 5$ & $0 \cdot 831$ & $-16 \cdot 0$ & $0.011^{*}$ \\
\hline Burger & $5 \cdot 4 / 1 \cdot 3$ & 0.975 & $3 \cdot 0$ & $0 \cdot 254$ & $1 \cdot 2$ & $0 \cdot 174$ & $-258 \cdot 1$ & $0.025^{\star}$ & $-3 \cdot 8$ & 0.489 & $1 \cdot 8$ & 0.626 \\
\hline Chicken & $-572 \cdot 4 /-136 \cdot 8$ & $0 \cdot 015^{\star}$ & $-7 \cdot 8$ & $0 \cdot 008^{*}$ & $-3 \cdot 2$ & $0 \cdot 000^{*}$ & $-483 \cdot 0$ & $0 \cdot 000^{*}$ & $-12 \cdot 2$ & $0.020^{*}$ & $-2 \cdot 8$ & 0.527 \\
\hline Italian & $-296 \cdot 2 /-70 \cdot 8$ & $0 \cdot 229$ & $-8 \cdot 8$ & $0 \cdot 010^{*}$ & $-0 \cdot 1$ & 0.948 & $-364 \cdot 3$ & $0 \cdot 012^{*}$ & $9 \cdot 9$ & 0.098 & $-13 \cdot 0$ & $0.001^{*}$ \\
\hline Mexican & $-196 \cdot 7 /-47 \cdot 0$ & 0.328 & $-4 \cdot 7$ & $0 \cdot 190$ & $-0 \cdot 2$ & 0.895 & $-17 \cdot 9$ & 0.886 & $9 \cdot 8$ & $0.024^{*}$ & $-7 \cdot 1$ & $0.012^{*}$ \\
\hline Pizza & $-1327 \cdot 6 /-317 \cdot 3$ & $0 \cdot 000^{*}$ & $-20 \cdot 1$ & $0 \cdot 000^{*}$ & $-6 \cdot 0$ & $0 \cdot 000^{\star}$ & $-1038 \cdot 5$ & $0 \cdot 000^{*}$ & $-9 \cdot 0$ & 0.330 & $-19 \cdot 7$ & $0.000^{*}$ \\
\hline Sandwich & $163 \cdot 2 / 39 \cdot 0$ & $0 \cdot 619$ & $-2 \cdot 1$ & $0 \cdot 636$ & $0 \cdot 1$ & 0.942 & $69 \cdot 6$ & 0.732 & $13 \cdot 9$ & 0.057 & $1 \cdot 5$ & 0.772 \\
\hline Snack & $31 \cdot 4 / 7 \cdot 5$ & $0 \cdot 854$ & $-2 \cdot 8$ & $0 \cdot 307$ & $0 \cdot 1$ & 0.963 & $-37 \cdot 7$ & $0 \cdot 744$ & $10 \cdot 5$ & $0.048^{*}$ & $-0 \cdot 7$ & 0.785 \\
\hline Steak/seafood & $-686 \cdot 6 /-164 \cdot 1$ & $0 \cdot 081$ & $-9 \cdot 4$ & $0 \cdot 223$ & $-0 \cdot 8$ & $0 \cdot 816$ & $-437 \cdot 3$ & $0 \cdot 035^{\star}$ & $-26 \cdot 1$ & $0.000^{*}$ & $2 \cdot 9$ & 0.534 \\
\hline \multicolumn{13}{|l|}{ Policy } \\
\hline$\%$ of outlets subject to menu labellingt & $0 \cdot 4 / 0 \cdot 1$ & 0.960 & $-0 \cdot 1$ & $0 \cdot 838$ & $0 \cdot 0$ & $0 \cdot 712$ & $-4 \cdot 0$ & 0.400 & $-0 \cdot 2$ & 0.456 & $0 \cdot 0$ & 0.907 \\
\hline$\%$ of outlets subject to trans fat bant & $5 \cdot 0 / 1 \cdot 2$ & $0 \cdot 014^{*}$ & $0 \cdot 0$ & $0 \cdot 225$ & $0 \cdot 0$ & $0 \cdot 029^{*}$ & $2 \cdot 0$ & 0.099 & $0 \cdot 1$ & $0.012^{*}$ & $0 \cdot 0$ & $0 \cdot 872$ \\
\hline \multicolumn{13}{|l|}{$\begin{array}{l}\text { Information accessibility (ref.: on website in a } \\
\text { single file/location) }\end{array}$} \\
\hline On website in multiple pages/per-item info & $344 \cdot 3 / 82 \cdot 3$ & $0 \cdot 177$ & $6 \cdot 7$ & 0.082 & $3 \cdot 3$ & $0.042^{*}$ & $-145 \cdot 9$ & $0 \cdot 285$ & $1 \cdot 8$ & 0.751 & $6 \cdot 0$ & $0 \cdot 019^{*}$ \\
\hline Not on website, provided upon email request & $607 \cdot 5 / 145 \cdot 2$ & $0 \cdot 001^{*}$ & $9 \cdot 1$ & $0 \cdot 000^{*}$ & $3 \cdot 4$ & $0 \cdot 002^{*}$ & $220 \cdot 4$ & $0 \cdot 045^{\star}$ & $8 \cdot 9$ & $0 \cdot 214$ & $6 \cdot 8$ & $0.043^{*}$ \\
\hline Prob $>F$ & 0.000 & & 0.000 & & 0.000 & & 0.00 & & $0 \cdot 000$ & & 0.000 & \\
\hline$R^{2}$ & 0.215 & & 0.179 & & 0.170 & & 0.13 & & 0.12 & & $0 \cdot 186$ & \\
\hline \multicolumn{13}{|l|}{$\begin{array}{l}\text { ref., reference category. } \\
{ }^{*} P<0 \cdot 05 . \\
+ \text { tScale: } 0-100 .\end{array}$} \\
\hline
\end{tabular}


size, and also must be interpreted in light of what is typically ordered and consumed at restaurant meals. Dumanovsky et al. found that in three fast-food restaurants, only $19.4 \%$ of purchases were single items, whereas $70.9 \%$ of purchases were dollar meal menu combinations of two or more items ${ }^{(34)}$. Market research data found that fast-food patrons order 2.4 menu items, on average, and that only $21 \%$ of children aged 6-12 years order kids' meals at fastfood restaurants ${ }^{(23)}$. That gives more cause for alarm, given the high sodium content in individual items. How people combine items may also differ across restaurant types and combination orders are likely to be different in family style restaurants compared with fast-food restaurants.

There were significant differences in nutritional content of menu items, particularly for some service types and cuisines. Some may be reporting artifices and reflect a limitation of how restaurants report data, including self-determined serving sizes (e.g. appetizers reported as multiple servings in some restaurants but not all). In particular, some pizza and fried chicken restaurants had surprisingly low energy content in main entrées because they used unusually small serving sizes (e.g. one slice of pizza, one chicken piece). This provides a clear indication that serving sizes need to be standardized for menu labelling to offer meaningful comparisons. There is less ambiguity in the finding that family-style restaurants offer items substantially higher in energy, fat and sodium. This may be due to larger portion sizes and/or higher energy density. Larger portion sizes can contribute to higher energy intake and weight gain over time in adults and children ${ }^{(35-39)}$. Family-style restaurants and, independently, American cuisine also offer main entrées with higher sodium levels. sodium intake in the USA is far higher than USDA-recommended levels, generating substantial social costs due to morbidity and excess health-care expenditures ${ }^{(40)}$.

While children's main entrées were lower in energy than regular menu ones, as they should be, children's menu specialty beverages were often dessert-like, sugary items such as milkshakes. They typically had more energy, fat and saturated fat than non-alcoholic, regular menu specialty beverages, which included more smoothies, coffee and tea specialty beverages. Over the past few decades, beverage-only snacking occasions have increased considerably in children ${ }^{(22)}$, and the percentage of energy intake from beverages increased in non-Hispanic black 12-19-year-olds ${ }^{(41)}$. School-based policies targeting sugarsweetened beverages have focused on soft drinks and vending machines; the present study provides data about specialty beverages served in restaurants.

The present data also show that the proportion of items meeting USDA, Healthy Dining and Kids LiveWell criteria is: (i) highly sensitive to specific criteria (e.g. a generous sodium threshold); (ii) substantially lower when nutrient values are considered in addition to energy; and (iii) potentially very different for USDA $v$. Healthy Dining and Kids LiveWell. Healthy Dining's sodium limit of $2000 \mathrm{mg}$ per main entrée could allow intake of up to $6000 \mathrm{mg}$ sodium/d across three meals $-2 \cdot 6$ times the USDA RDA for adults and four times that for adults with low sodium needs without considering other items ordered. Many items met a single nutrition criterion, but far fewer satisfied multiple criteria. Thus, many items that may be perceived as falling within USDA-recommended levels based on energy alone, which is the only value that will be added to menus under ACA, would not meet other nutritional standards. Finally, a much larger proportion of main entrées could meet Healthy Dining and Kids LiveWell criteria, compared with one-third of the USDA RDA limits, suggesting that restaurant industry-supported criteria are more generous than government-established ones. Although comparisons were based on partial data (e.g. without sugar, ingredients), it is clear that restaurant industry-supported criteria differ from USDA ones - particularly for sodium. The Healthy Dining and Kids LiveWell logos are used on many chain restaurants' menus to highlight 'healthy choices', but they provide a vastly different picture from USDA guidelines. Misleading health claims used by grocery manufacturers on front-of-package labelling has been a concern for federal regulators ${ }^{(42)}$. The present study provides evidence that restaurant industry labelling also deserves further discussion.

\section{Conclusions}

There is not compelling evidence that labelling alters individual choices from a fixed menu, but restaurant menus change over time, and the present study provides baseline data just before national labelling laws came into effect that can be used to assess such changes. Many restaurant menu items are high in fat, saturated fat and sodium, and restaurant industry-supported logos used to highlight 'healthy choices' are more generous than USDA recommendations, particularly for sodium. Menu items that appear reasonable based on energy alone must be considered within the context of an entire meal and for other nutrient values. Sometimes those extras, such as children's specialty beverages, are problematic.

\section{Acknowledgements}

This research was supported by grant \#68302 from Healthy Eating Research, a national programme of the Robert Wood Johnson Foundation, and by the JL Foundation. The authors have no conflicts of interest to report. H.W.W. conceptualized the study and obtained funding, designed the study, collected and analysed data, and wrote the initial manuscript. R.S. contributed to the proposal and study design, oversaw the statistical analysis, and revised the manuscript. The authors greatly appreciate the data gathering assistance provided by Adrian Overton and analysis support provided by Adam Gailey. 


\section{References}

1. US Department of Agriculture, Economic Research Service (2010) Diet quality and food consumption: flexible consumer behavior survey. http://www.ers.usda.gov/Briefing/ DietQuality/flexible.htm (accessed July 2011).

2. Kant A \& Graubard B (2004) Eating out in America, 1987-2000: trends and nutritional correlates. Prev Med 38, 243-249.

3. Todd JE, Mancino L \& Lin B-H (2010) The Impact of Food Away from Home on Adult Diet Quality. Economic Research Report no. 90. Washington, DC: USDA Economic Research Service; available at http://www.ers.usda.gov/ publications/err90/err90.pdf

4. Pomeranz J (2011) The unique authority of state and local health departments to address obesity. Am J Public Health 101, 1192-1197.

5. Department of Health and Human Services \& Food and Drug Administration (2011) Food labeling; nutrition labeling of standard menu items in restaurants and similar retail food establishments - proposed rule. Federal Register 76, 19191-19236.

6. Girz L, Polivy J, Herman C et al. (2011) The effects of calorie information on food selection and intake. Int J Obes (Lond) (Epublication ahead of print version).

7. Finkelstein EA, Strombotne KL, Chan NL et al. (2011) Mandatory menu labeling in one fast-food chain in King County, Washington. Am J Prev Med 40, 122-127.

8. Roberto C, Larsen P, Agnew H et al. (2010) Evaluating the impact of menu labeling on food choices and intake. $A m \mathrm{~J}$ Public Health 100, 312-318.

9. Harnack L \& French S (2008) Effect of point-of-purchase calorie labeling on restaurant and cafeteria food choices: a review of the literature. Int J Behav Nutr Phys Act 5, 51.

10. Harnack L, French S, Oakes J et al. (2008) Effects of calorie labeling and value size pricing on fast food meal choices: results from an experimental trial. Int J Behav Nutr Phys Act 5, 63.

11. Elbel B, Kersh R, Brescoll V et al. (2009) Calorie labeling and food choices: a first look at the effects on low-income people in New York City. Health Aff (Millwood) 28, w1110-w1121.

12. Wootan M \& Osborn M (2006) Availability of nutrition information from chain restaurants in the United States. $A m$ J Prev Med 30, 266-268.

13. Harnack L (2006) Availability of nutrition information on menus at major chain table-service restaurants. J Am Diet Assoc 106, 1012-1015.

14. Harris JL, Schwartz MB, Brownell KD et al. (2010) Fast Food FACTS: Evaluating Fast Food Nutrition and Marketing to Youth. New Haven, CT: Yale-Rudd Center for Food Policy \& Obesity; available at http://fastfoodmarketing.org/ media/FastFoodFACTS_Report.pdf

15. Nielsen SJ \& Popkin BM (2003) Patterns and trends in food portion sizes, 1977-1998. JAMA 289, 450-453.

16. Restaurants \& Institutions magazine (2009) 2009 top 400 restaurant chains. http://www.rimag.com/article/372414-R_I_2009_ Top_400_Restaurants_Chains.php (accessed February 2010).

17. Infogroup (2010) InfoUSA, US Business list. http://www. infousa.com

18. California Conference of Directors of Environmental Health (2009) California menu labeling guidelines. http://www. emd.saccounty.net/EnvHealth/FoodProtect/MenuLabeling. html (accessed August 2011).

19. Healthy Dining (2011) Healthy Dining Finder nutrition criteria. http://www.healthydiningfinder.com/ (accessed July 2011).

20. US Department of Agriculture \& US Department of Health and Human Services (2010) Dietary Guidelines for Americans, 7th ed. Washington, DC: US Government Printing Office.

21. US Department of Agriculture \& US Department of Health and Human Services (2010) Dietary Guidelines for Americans, 7th ed., p. 14. Washington, DC: US Government Printing Office.

22. Popkin BM \& Duffey KJ (2010) Does hunger and satiety drive eating anymore? Increasing eating occasions and decreasing time between eating occasions in the United States. Am J Clin Nutr 91, 1342-1347.

23. The NPD Group/CREST (2010) Two years ending December 2009. As cited in Fast Food FACTS: Evaluating Fast Food Nutrition and Marketing to Youth [JL Harris, MB Schwartz and KD Brownell et al.]. New Haven, CT: YaleRudd Center for Food Policy and Obesity; available at http:// fastfoodmarketing.org/media/FastFoodFACTS_Report.pdf

24. Institute of Medicine Committee on Nutrition Standards for National School Lunch and Breakfast Programs (2010) School Meals: Building Blocks for Healthy Children [VA Stallings, CW Suitor and CL Taylor, editors]. Washington, DC: The National Academies Press.

25. Restaurantchains.net (2011) Research Report for Foodservice. http://www.restaurantchains.net/ (accessed 15 March 2011).

26. Centers for Disease Control and Prevention (2011) Database of state legislative and regulatory action to prevent obesity and improve nutrition and physical activity. http://apps.nccd. cdc.gov/DNPALeg/index.asp?Types=2 (accessed May 2011).

27. National Conference of State Legislatures (2011) Bill information service - trans fat and menu labeling information. http:// www.ncsl.org/default.aspx?tabid=14362 (accessed May 2011)

28. Center for Science in the Public Interest (2010) State and local menu labeling policy map. http://cspinet.org/new/ pdf/ml_map.pdf (accessed May 2011).

29. Center for Science in the Public Interest (2011) Trans fat bans in restaurants. http://www.cspinet.org/transfat/index. html (accessed May 2011).

30. Guthrie JF, Lin BH \& Frazao E (2002) Role of food prepared away from home in the American diet, 1977-78 versus 1994-96: changes and consequences. J Nutr Educ Behav 34, 140-150.

31. Food Service Research Institute (undated) MenuMine brochure. http://foodserviceresearchinstitute.com/downloads/ MenuMineBrochure.pdf (accessed February 2012).

32. Glanz K, Resnicow K, Seymour J et al. (2007) How major restaurant chains plan their menus: the role of profit, demand, and health. Am J Prev Med 32, 383-388.

33. Saelens B, Glanz K, Sallis J et al. (2007) Nutrition environment measures study in restaurants (NEMS-r): development and evaluation. Am J Prev Med 32, 273-281.

34. Dumanovsky T, Nonas C, Huang C et al. (2009) What people buy from fast-food restaurants: caloric content and menu item selection, New York City 2007. Obesity (Silver Spring) 17, 1369-1374.

35. Duffey KJ \& Popkin BM (2011) Energy density, portion size, and eating occasions: contributions to increased energy intake in the United States, 1977-2006. PLoS Med 8, e1001050.

36. Rolls BJ, Roe LS \& Meengs JS (2007) The effect of large portion sizes on energy intake is sustained for 11 days. Obesity (Silver Spring) 15, 1535-1543.

37. Ello-Martin JA, Ledikwe JH \& Rolls BJ (2005) The influence of food portion size and energy density on energy intake: implications for weight management. Am J Clin Nutr 82, 1 Suppl., 236S-241S.

38. Fisher J, Liu Y, Birch L et al. (2007) Effects of portion size and energy density on young children's intake at a meal. Am J Clin Nutr 86, 174-179.

39. Kelly MT, Wallace J, Robson PJ et al. (2009) Increased portion size leads to a sustained increase in energy intake over $4 \mathrm{~d}$ in normal-weight and overweight men and women. Br J Nutr 102, 470-477.

40. Palar K \& Sturm R (2009) Potential societal savings from reduced sodium consumption in the US adult population. Am J Health Promot 24, 49-57.

41. Kant AK \& Graubard BI (2011) 20-Year trends in dietary and meal behaviors were similar in U.S. children and adolescents of different race/ethnicity. J Nutr 141, 1880-1888.

42. Pomeranz JL (2011) Front-of-package food and beverage labeling. Am J Prev Med 40, 382-385. 